\title{
Geopolitical Aspect in the Studies of Education Environment
}

\author{
Marina F. Kuznetsova* \\ Siberian Federal University \\ 79 Svobodny, Krasnoyarsk, 660041, Russia
}

Received 16.02.2015, received in revised form 29.04.2015, accepted 10.05.2015

The present article is dedicated to the brief analysis of interdependence between the geopolitical and education media in the modern world. It studies such geopolitical and educational concepts as globalization and internationalization, "Americanization" and "Europeanization"; analyses the role of mentality as a geopolitical and educational construct. It substantiates the urgency of education as one of the principal tools for forming a new geopolitical model of the world. It arrives at the conclusion that geopolitical relationships between states are mainly determined and regulated by the level of their national education systems' development.

The social-philosophic analysis of functioning and reformation of the education sphere under modern geopolitical conditions demonstrated that "such concepts as "education" and "globalization" are often ambiguously interpreted. The process of education activity globalization is evaluated in a similar ambiguous way. Understanding and adequate evaluation of the current processes and phenomena depend on the temporal and culture-philosophical context.

Bearing great significance in both geopolitical and educational aspect, the concept of Europeanization deserves special attention. "In the universal development process Europeanization, on one hand, is a part of globalization (especially in the sphere of education) and a mini project of Europe as a miniature world model with unified standards, requirements, common governmental units etc. On the other hand, Europeanization is a process of separation and union of certain states to spite the rest of the world, of spreading European values and traditions, of integrating of their projects into the universal space in order to increase their status, power, scale, and self-perfection as a world unit".

Therefore, "Americanization" and "Europeanization" of education activities act as alternative models of globalizations competing one with another in the general system of occurring geopolitical and educational processes.

Another fact to be considered is that the mental cultural and historical predisposition of certain societies is seen as a more or less stable characteristic, determining the core of all their internal metamorphoses and development, thereby allowing some forecasting of educational systems' behaviour (though approximately) in the currently established geopolitical conditions, whether they can follow the way of the suggested reforms or they select their own path.

The inefficiency of copying reforms successful in some societies is frequently determined by the fact that their ideologists do not account for the mentality of the community the reforms are imposed on, the community taking reforms as something alien, standing beyond its customary world model.

Historical determination of mentality manifests itself in the fact that mentality cannot be forced up on a nation as it often happens in the period of reforms, but, as we have mentioned above, it is formed naturally, developed with a historically determined unity of natural, geographic, ethnical, geopolitical

(C) Siberian Federal University. All rights reserved

* Corresponding author E-mail address: mfkuznecova@mail.ru 
and other objective peculiarities independent of the nation itself and characterizing the area of its habitat. In fact, we should notice that in the past decades the national and international management has been based on the economic centerpiece: politics, education, science, industry etc. are gradually turned into an economic appendage, or, in other words, it means commercialization of all spheres of the human life. It raises another fact that within the new universal educational concept the dominating role is always played by economically developed countries alone, regarding their position as a sort of monopoly at the education market: education is invested in, it is exported and imported, in other words, it is used as a market capital. This external aspect of changes in the education system has formed the inner core of education medium transformation.

The current world geopolitical situation determines the requirements set for the today's higher education: university (as the basic higher education institution) is intended to create a specialist conforming to the established requirements of the socioeconomic market. The specialist must be mobile, flexible, open to innovations, able to process rapid flows of information (ready to train and re-qualify), ready for frequent international contacts, living and working in the "uniplanetary" world; at the same time, be adequate in interpreting the meaning of globalness, globalization, integration and internationalization of any sphere of life.

Keywords: geopolitics, education, mentality, globalization, internationalization, Americanization, Europeanization.

Research area: philosophy.

Introduction. One of the most urgent problems of the humankind at the turn of Millennium is the problem of education. The questions on the prospective of the modern national education systems and the possible consequences of dramatic reconstruction remain disputable, having no absolute answer. The question on the interdependence of geopolitical situation in the world and the transformation of the education medium remains at the same stage of discussion. There are more and more new aspects of the problem coming up. All these questions, and, mostly, the absence of absolute answers to them, prove the urgency of the current topic. The purpose of the present research is to reveal the interdependence in solving the problems of geopolitics and education. In order to achieve the purpose set in the article it appears necessary to reveal the correlation between globalization and internationalization phenomena; to trace the interaction between the two globalization centres ("Americanization" and "Europeanization") in the sphere of education and geopolitics; to analyse the role of mentality as a geopolitical and educational construct; to review the geopolitical opportunities for integrating national educational systems into the universal education environment.

Methodology. Study of the existing regulatory and legal documents and researches on the present topic and direct analysis of the certain facts of the modern educational environment development brings us to the significant conclusions defining the essence of the chosen problem.

Discussion. So, social-philosophic analysis of functioning and reformation of the education system in the modern geopolitical condition demonstrated that "such concepts as "education" and "globalization" are often ambiguously interpreted. The process of education activity globalization is evaluated in a similar ambiguous way. Understanding and adequate evaluation of the current processes and phenomena depend on the temporal and culture-philosophical context. For instance, in the $21^{\text {st }}$ century the attitude to education was radically changed (and not in the terminological aspect only). It was stimulated by the accelerating scientific and technical progress, change of emphases in international politics and economy. It is more than just perception of 
personality and the state's attitude to it that has changed; there have been changes in concepts and reappraisal of values. For instance, pursuance of material goods, commercialization of all spheres of human activity have transformed knowledge into a resource a person needs to consume in order to produce new resources" (Kuznetsova M.F. (2012). Filosofiia obrazovatel'nykh reform $v$ usloviiakh sovremennoy globalizatsii [Philosophy Of Education Reforms In The Context Of Modern Globalization] // V.P. Astafiev Krasnoyarsk State Pedagogical University Newsletter, 4 (22), 361366).

The instability of today's world relations has stimulated realization of the social crisis in its geopolitical and educational aspects. The modern education systems of all states rely on apprehension of the present world through the prism of education philosophy. Having realized the challenges in resolving global problems leading to world cataclysms, the global community has launched the policy of integration and internationalization. A great number of new educational projects and, therefore, of new reforms, usually emerges at the crucial points in social development, which justifies both the tight interconnection between education, politics and economy and the ability of education to solve problems in the mentioned spheres. At the same time, we cannot ignore the fact that globalization processes act as imposing of its education projects by the globalization leaders, while internationalization of education activity assumes the necessity of assimilation of each project to the peculiarities of each society's lifestyle.

It is worthwhile noticing that the geopolitical concept of uniplanetarity which is regularly correlated to the concept of globalness, often demonstrates its fragmentariness and conventionality. As a rule, there are only large and significant in the international arena developed countries that get caught in the lens of globalism.
It allows multiple researchers to speak of the process or phenomenon of globalization when analysing the phenomena or processes in the EU, USA, Japan, sometimes Russia and China. It is not only non-involvement of the third-world and other countries into the process, it is the fact of such countries' not even being taken into account; no one assumes that such processes should cover any countries beyond the list. Therefore, the concept of globalization is sometimes a cover for the terms of Europeanization, Americanization, "Westernization" and alike.

Speaking of the geopolitical aspect in the education environment, we should not miss the fact that today there are grounds for dividing the general concept of globalization into two types: natural and artificial, or, to be more precise, into natural and artificial processes. In such a case, natural globalization refers to the processes associated with information technology development, application of means and results of scientific and technical progress, migrations, general evolutionary (social and biological) changes etc. As a rule, it is based on natural communication and the need for such. Artificial globalization manifests itself in different international associations, projects, and organizations. It covers a great variety of fields: politics, economy, culture, education etc. As a rule, it is based on a convention or a series of conventions about certain patterns of behaviour and actions, on conformity to a certain documented and institutionalized standard by several subjects. Examples of such are: the UN, UNESCO, WTO, IMF, World Bank, Bologna process (in the field of education) etc.

As we can see, globalization is a nonlinear, wave-like and sophisticated phenomenon, ambiguously interpreted in both geopolitical and educational aspects. The changes introduced into different spheres and aspects by the globalization process lead to both positive and 
negative consequences. For example, technology development provides the opportunity to increase the safety of many lines of activity, but on the other hand, it may transform into a destructive power arsenal (terrorism, organized crime etc.) Globalization is a manifestation of immensity, penetrance, sometimes virtuality (virtual capitals, virtual institutions etc.). It requires standardization, formulation, and institutionalization. Different social institutions may simultaneously act as both a consequence and an instrument of globalization (which especially concerns economic and political institutions).

The concept of Europeanization, significant in both geopolitical, and educational aspects, deserves special attention. "In the universal development process Europeanization, on one hand, is a part of globalization (especially in the sphere of education) and a mini project of Europe as a miniature world model with unified standards, requirements, common governmental units etc. On the other hand, Europeanization is a process of separation and union of certain states to spite the rest of the world, of spreading European values and traditions, of integrating of their projects into the universal space in order to increase their status, power, scale, and selfperfection as a world unit " (Kuznetsova, M.F. (2012). Regional'nye osobennosti global'nogo obrazovatel'nogo prostranstva [Regional Peculiarities Of The Global Educational Environment] // Filosofiia v soveremennom mire: dialog mirovozzreniy [Philosophy In The Modern World: Dialogue Of Word Views]: Proceedings of the VI Russian Philosophic Congress (Nizhny Novgorod, June 27-30, 2012), in 3 volumes. Vol. 3. Nizhny Novgorod: N.I. Lobachevsky Niznny Novgorod University Press, 99).

Therefore, Europe attempts to maintain its dominating position and strengthen its leadership in the globalizing world, or, at least, not to allow the unipolarity dictated by the USA (with its Americanization project) at least in the education environment, let alone geopolitical. Therefore, Americanization and Europeanization of the education activity act as the alternative models of globalization, competing one against another within the general system of geopolitical and educational processes of globalization. Notably, the recent events reveal the tendency of strengthening the American geopolitical influence in the international arena in spite the strengthening geopolitical status of Russia. Such acute "rivalry" leads the world to the elimination of unipolarity and to establishment of new political and economic accents. The role of Europeanization as a geopolitical process is minimized, but strengthened as that of a process in the education environment. Here we observe the education centerpoint principle: as soon as the state becomes aware of the change in its international status (weakening or strengthening) leading to a deep national economic and culturalsocial crisis, it launches enhanced control and analysis of the national education system. It seeks for the educational causes of the crisis and the possibilities to get over it using education as an instrument to develop national mission and patriotism and as a source of qualified specialists to fulfil the requirements of politics and economy. In the present time such changes cover universal education environment as a whole, but they are especially distinctive in Europe and Russia. Such situation encourages optimism about the future of Russian education, its adequate reformation and stabilization. As for modern geopolitical and educational situation of the USA, it mostly emphasizes the international militarized influence and, consequently, correction of education medium in this and adjacent spheres in order to maintain the tottering world hegemony. It is worthwhile noticing that various national educational projects (European, Russian, etc.) have been formed throughout decades and even 
centuries, proven by time and various forms of social and political instability. Not being closed and isolated completely, such projects can give an adequate response to the global changes happening in the world today. It is hoped that the orientation for the internal and specific traits, such as mentality, culture, type of society and state administration etc., i.e. on everything which, in reasonable correlation, determines comfortable, harmonic development of the society, shall remain the major priority in selecting the further path of education development. The foreignness of the reforms imposed from outside is especially evident in the situations when the exporting and importing parties (i.e. the systems creating the reforms, projects, or systems, implementing and absorbing them) are, in fact, different types of civil society. Another fact to be considered is that mental, cultural and historical predispositions of certain societies are seen as a more or less stable characteristic, determining the core of all their internal metamorphoses and development, thereby allowing some forecasting of educational systems' behaviour (though approximately) in the currently established geopolitical conditions, whether they can follow the way of the suggested reforms or they select their own path.

We may call the drawn out "reformation" of the social values and instability of life objectives one of the true major characteristics of the modern stage of humankind development. It is especially acute in the sphere of Russian culture and economy modernization. The inefficiency of copying reforms successful in some societies is frequently determined by the fact that their ideologists do not account for the mentality of the community the reforms are imposed on, the community taking reforms as something alien, standing beyond its customary world model. "Mentality can be defined as general spiritual tune, a relatively integral unity of thoughts, beliefs, spiritual abilities, which creates the world outlook and collaborates the unity of the cultural tradition or a society. Mentality characterizes some special levels of individual and collective consciousness as well as the unconscious; in this regard mentality presents a specific way of thinking. Including the collective unconscious, mentality expresses the life objectives and practical targets of people, some sustainable images of the surrounding world, emotional preferences typical for this community and this cultural tradition" (Kuznetsova M.F. (2011). Mentalitet kak modeleobrazuiuschaia konstanta [Mentality As Model-Shaping Constanta] // V.P. Astafiev Krasnoyarsk State Pedagogical University Newsletter, 4 (18), 192-195).

The concept of mentality allows us to find a connection between analytical thinking and halfconscious cultural cyphers. Within mentality, there may be different oppositions: natural and cultural, emotional and logical, irrational and rational, individual and social. Social behaviour is not continuous analytic activity. A certain individual's evaluation of this or that phenomenon is influenced by their previous experience, common sense, and interest. Therefore, "mentality is the common element borne by the natural and socially determined components that reveals the person's idea of the world they live in. The skills of perceiving the surrounding environment, the thinking patterns, and image complexes find their cultural incarnation in the mentality" (Prokaeva O.N. Dukhovno-tsennostnyy smysl mentaliteta [Spiritual And Axiological Significance Of Mentality]. Saransk, 2004. 205 p.).

National mentality is the common base for the development of sociocultural processes and phenomena during the whole process of development of the given nation and its culture. For each national culture this common base is a unity of the most significant historical and not necessarily historical (or over-historical) conditions, such as geographic location, 
landscape, biosphere and other habitat indicators, fundamental features of a certain ethnos and its closest ethnical surrounding and other factors. Being directly associated with its geopolitical development, such unity of traits determines the idea of the national originality and culture. National originality is manifested in the national character and the national historical fate, in the national world outlook i.e. the national forms of world perception, world observance, thinking and theorizing revealed in mythology, folklore, customs and traditions, religious cult, and then in philosophy, literature, art, in the social, political, governmental, legal, moral and ethical selfidentification of the nation.

Historical determination of mentality manifests itself in the fact that mentality cannot be forced up on a nation as it often happens in the period of reforms, but, as we have mentioned above, it is formed naturally, developed with a historically determined unity of natural, geographic, ethnical, geopolitical and other objective peculiarities independent of the nation itself and characterizing the area of its habitat. Basically, mentality is one of the major geopolitical and educational constructs that unites these two contexts and proves their interdependence, thereby explaining the fact that education today serves as one of the most important tools for creating a new geopolitical model of the world. It causes significant strengthening of the bonds between the education systems and economy (national and universal). In fact, we should notice that in the past decades the national and international management has been based on the economic centerpiece: politics, education, science, industry etc. are gradually turned into an economic appendage, or, in other words, it means commercialization of all spheres of the human life. It raises another fact that within the new universal educational concept the dominating role is always played by economically developed countries alone, regarding their position as a sort of monopoly at the education market: education is invested in, it is exported and imported, in other words, it is used as a market capital. This external aspect of changes in the education system has formed the inner core of education medium transformation.

The current world geopolitical situation determines the requirements for the today's higher education: university (as the basic higher education institution) is intended to create a specialist conforming to the established requirements of the socioeconomic market. The specialist must be mobile, flexible, open to innovations, able to process the rapid flow of information (ready to train and re-qualify), ready for frequent international contacts, living and working in the "uniplanetary" world; at the same time, be adequate in interpreting the meaning of globalness, globalization, integration and internationalization of any sphere of life.

Conclusion. To make a general conclusion we shall notice that geopolitical aspect in education environment studies has a great significance on both global and national levels. The internal task of modern education is formulated as creating a system for focused preparation of professionals to form a highly qualified candidate pool for various branches of industry. Professionalism is not the only feature required from the future specialists; another one is patriotism based on true spirituality and morality. Such people are necessary for resolving the geopolitical problems of the modern time as collateral of productive functioning of all the scientific, industrial, socioeconomic branches and state ministries including Ministry of education. The interdependence of the educational and geopolitical environments is evident. Speaking with commercialized terms and language adequate to the modern reality, timely investment into the education system, rationalized resolution of the current problems 
will gradually turn into investments into the future of the present country and the world as a whole. Being long-term, such investments do not bring any immediate results, thereby being ignored by the state which prefers faster, though less efficient methods of geopolitical regulations. Unfortunately, out world is not perfect, and our reality is full of geopolitical threats (wars, territory occupation, aggressive economy etc.). It is only a strong state system with a powerful scientific, industrial, sociocultural, militarypolitical and spiritual-moral human potential that can withstand the onslaught. All these features are capable of providing the adequately sustained education, strictly regulated by the state itself. For this reason studies of the educational environment, let alone any transformation of the educational environment seem possible only with regard to the modern geopolitical situation in the world.

\section{References}

1. Borozdinov V.S., Deliia V.P., Luk'ianchikov N.N. Paradigma planetarnogo mirovozzreniia $X X I$ veka (mezhdunarodnyy, sotsial'no-ekonomicheskiy i dukhovnyy aspekty) [Paradigm Of The Planetary World Outlook Of The $21^{\text {st }}$ Century (International, Socioeconomic And Spiritual Aspects]. Balashikha, 2011. $256 \mathrm{p}$.

2. Dneprov E.D. Noveyshaia politicheskaia istoriia rossiyskogo obrazovaniia: opyt $i$ uroki [The Latest Political History Of Russian Education: Experience And Lessons]. Moscow: Marios, 2011. $472 \mathrm{p}$.

3. Kuznetsova M.F. (2011). Mentalitet kak modeleobrazuiuschaia konstanta [Mentality As Model-Shaping Constanta] // V.P. Astafiev Krasnoyarsk State Pedagogical University Newsletter, 4 (18), 192-195.

4. Kuznetsova, M.F. (2012). Regional'nye osobennosti global'nogo obrazovatel'nogo prostranstva [Regional Peculiarities Of The Global Educational Environment] // Filosofiia v soveremennom mire: dialog mirovozzreniy [Philosophy In The Modern World: Dialogue Of Word Views]: Proceedings of the VI Russian Philosophic Congress (Nizhny Novgorod, June 27-30, 2012). Vol. 3. Nizhny Novgorod: N.I. Lobachevsky Niznny Novgorod University Press, 99.

5. Kuznetsova M.F. (2012). Filosofiia obrazovatel'nykh reform v usloviiakh sovremennoy globalizatsii [Philosophy Of Education Reforms In The Context Of Modern Globalization] // V.P. Astafiev Krasnoyarsk State Pedagogical University Newsletter, 4 (22), 361-366.

6. Prokaeva O.N. Dukhovno-tsennostnyy smysl mentaliteta [Spiritual And Axiological Significance Of Mentality]. Saransk, 2004. 205 p. 


\section{Геополитический аспект}

\section{в исследовании образовательного пространства}

М.Ф. Кузнецова

Сибирский федеральный университет Россия, 660041, Красноярск, пр.Свободный, 79

Статья посвящена краткому анализу взаимообусловленности геополитического и образовательного пространства в современном мире. Рассматриваются такие геополитические и образовательные реалии, как глобализация и интернационализация, «американизация» и «европеизачия», анализируется роль менталитета как геополитического и образовательного конструкта. Обосновывается актуальность точки зрения на образование как на один из наиболее важных инструментов для создания новой геополитической модели мира. Делаются выводы о том, что геополитические отношения между государствами во многом определяются и регулируются уровнем развития их начиональных образовательных систем.

Сочиально-философский анализ функиионирования и реформирования сферы образования в современных геополитических условиях показал, что «такие понятия, как «образование» и «глобализация», часто трактуются неоднозначно, так же как неоднозначно оценивается и сам процесс глобализации образовательной деятельности. Понимание и оценка протекающих процессов и явлений зависит от временного и культурно-философского контекста.

Особо нужно сказать о понятии «европеизация», немаловажном как в геополитическом, так и в образовательном аспектах. «Европеизация в процессе общепланетарного развития, с одной стороны, является частью глобализации (особенно в сфере образования), её минипроектом - Европа как уменьшенная модель мира с едиными требованиями, стандартами, общими управленческими организачиями и т.д. С другой стороны - европеизация становится проиессом отсорбирования и сплочения отдельных государств в пику прочему окружающему миру; распространяя европейские ценности и традиции, интегрируя свои проекты в мировое пространство с иелью повышения своего статуса, мощи, масштабности, усовершенствования себя как мировой единицы».

Таким образом, «американизация» $u$ «европеизация» образовательной деятельности выступают как альтернативные модели глобализации, конкурирующие между собой в общей системе реализачии глобализационных геополитических и образовательных процессов.

Необходимо учитывать и тот факт, что ментальная культурно-историческая предрасположенность отдельных обществ представляется характеристикой более или менее постоянной, определяющей сущность любых их внутренних преобразований и развития, становится возможным прогнозированием (пусть на вариативном уровне) поведения национальных образовательных систем в сложившихся геополитических условиях, смогут ли они пойти по пути предлагаемых реформ или изберут собственный путь.

Неэффективность копирования удачных в иных обществах реформ зачастую связана с тем, что их идеологи абсолютно не учитывают менталитет общности, которой эти реформь навязываются и для которой они, по сути, являются чужеродными, находящимися за пределами принятой обществом модели мира.

Историческая обусловленность менталитета проявляется и в том, что менталитет не может быть насильно навязан народу извне, как это часто происходит в эпоху реформ, а формируется, как об этом говорилось выше, естественным путем, порождается исторически возникшей совокупностью природно-географических, этнических, геополитических и других объективно существующих и не зависящих от народа особенностей, характеризующих ареал его проживания. Вообще в последние десятилетия государственное и международное устроительство базируется на экономической доминанте: политика, образование, наука, 
промышленность и прочее постепенно превращаются в экономический придаток или, иначе говоря, речь идёт о коммерииализации всех сфер человеческой жизни. Отсюда проистекает и тот факт, что в новой мировой образовательной концепции диктующая роль принадлежит лишь экономически развитым странам, которые рассматривают свою доминирующую позицию как своего рода монополию на рынок образовательных услуг: в образование делаются инвестиции, оно экспортируется и импортируется, словом, рассматривается как рыночньии капитал. Это внешняя сторона происходящчих в образовании перемен сформулировала и саму внутреннюю суть трансформации образовательного пространства.

Сложившаяся в современном мире геополитическая ситуация обусловливает и требования, предъявляемые к высшему образованию сегодня: университет как основной образовательный институт высшей ступени должен создать человека-специилиста, отвечающегосложившимся запросам сочиильно-экономического рынка. Специалист должен быть мобильным, гибким, готовым воспринимать различные инновации, освачвать быстроменяющийся поток информации (m. е. постоянно доучиваться $и$ переучиваться), быть готовым к частым межнациональным контактам, жить и работать в условиях «единопланетарности» мира; при этом адекватно трактовать само значение глобальности, глобализации, интеграции и интернационализации любой жизненной сферы.

Ключевые слова: геополитика, образование, менталитет, глобализаџия, интернационализаџия, «американизащия», «европеизачия».

Научная специальность: 09.00.00 - философские науки. 